\title{
Accelerated immunosenescence in rheumatoid arthritis: impact on clinical progression
}

\author{
Moisés E. Bauer
}

\begin{abstract}
Patients with rheumatoid arthritis (RA) develop features of accelerated ageing, including immunosenescence. These changes include decreased thymic functionality, expansion of late-differentiated effector $T$ cells, increased telomeric attrition, and excessive production of cytokines (senescence-associated secretory phenotype). The progression of RA has been associated with the early development of age-related co-morbidities, including osteoporosis, cardiovascular complications, and cognitive impairment. Here I review data supporting the hypothesis that immune-senescence contributes to the aggravation of both articular and extra-articular manifestations. Of note, poor cognitive functions in RA were associated with senescent CD28- T cells, inflammaging, and autoantibodies against brain antigens. The pathways of immune-to-brain communication are discussed and provide the rationale for the cognitive impairment reported in RA.
\end{abstract}

Keywords: Rheumatoid arthritis, Ageing, Cell senescence, Immune ageing, Cognitive impairment

\section{Introduction}

Rheumatoid arthritis (RA) is a systemic chronic inflammatory disease, causing symmetrical and destructive inflammation in joints as well as in multiple tissues. It occurs in approximately $1 \%$ of the world's population and is more frequent in women than in men, at a 3:1 ratio [1]. In the initial phase of the disease, patients develop mostly articular manifestations, particularly in the knee and hand synovial joints. During disease progression, RA is also associated with extra-articular manifestations including, among others, cardiovascular disease, vasculitis, rheumatoid nodules, and cognitive impairment $[2,3]$.

RA is an autoimmune disease and its pathogenesis includes the recognition of self-antigens that are locally expressed in the synovial tissue. Candidate antigens

Correspondence: mebauer@pucrs.br

Laboratory of Immunobiology, School of Health and Life Sciences, Pontifical Catholic University of Rio Grande do Sul (PUCRS), Av. Ipiranga, 6681, Porto Alegre, RS 90619-900, Brazil

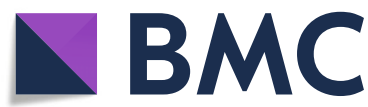

include type II collagen, the proteoglycans, and the cartilage protein gp39 [4-6]. These antigens have been clearly implicated in autoimmunity and the development of experimental arthritis in rodents. However, their importance for RA pathogenesis has not been unequivocally established in humans. The aetiology of RA has multifactorial contributions of both genetic and environmental triggers to the onset and development of the disease. The presence of certain alleles in the human leukocyte antigen (HLA)-DRB1 gene, such as DRB1*04: 01, are strongly associated with RA [7]. These risk alleles encode a five amino acid sequence referred to as a shared epitope at positions $70-74$ on the HLA-DR $\beta$ chain. The presence of the shared epitope in HLA favours the binding of self-proteins that have undergone post-translational modification in a process referred to as citrullination - a physiological process that can be intensified by the presence of a risk allele in the PTPN22 gene, which is also a genetic risk factor for RA, as well as exposure to tobacco smoke [2]. In addition, gender

(c) The Author(s). 2020 Open Access This article is licensed under a Creative Commons Attribution 4.0 International License, which permits use, sharing, adaptation, distribution and reproduction in any medium or format, as long as you give appropriate credit to the original author(s) and the source, provide a link to the Creative Commons licence, and indicate if changes were made. The images or other third party material in this article are included in the article's Creative Commons licence, unless indicated otherwise in a credit line to the material. If material is not included in the article's Creative Commons licence and your intended use is not permitted by statutory regulation or exceeds the permitted use, you will need to obtain permission directly from the copyright holder. To view a copy of this licence, visit http://creativecommons.org/licenses/by/4.0/ The Creative Commons Public Domain Dedication waiver (http://creativecommons.org/publicdomain/zero/1.0/) applies to the data made available in this article, unless otherwise stated in a credit line to the data. 
(female), advanced age, and certain foods have been associated with increased risk for developing the disease [8].

Currently, the development of RA is divided into three stages of progression that can be described as follows: (1) preclinical phase, (2) clinical phase and (3) extraarticular manifestations. The first stage comprises the onset of autoimmunity, without clinical manifestations. In the second phase, the dysregulation of regulatory mechanisms, marked by the reactivity of $B$ and $T$ cells against self-antigens, triggers strong inflammatory responses that highlight the clinical onset of the disease. As the disease progresses, joint and extra-articular manifestations become noticeable (3rd stage) [9].

There are two major mechanisms involved in the immunopathogenesis of RA. First, the intimal lining of the joint greatly expands leading to the increase and activation of synoviocytes. These cells secrete several proinflammatory cytokines, including tumour necrosis factor (TNF), interleukin (IL)-1, IL-6, proteinases (e.g., metalloproteinases or MMPs) and lipid mediators like prostaglandins and leukotrienes [1]. The synovial invasion into adjacent articular structures damages the cartilage and bone and is a hallmark of RA, characterized by joint swelling. Second, hyperplasia of the synovial layer contributes to the recruitment of neutrophils and lymphocytes (mostly $\mathrm{T}$ and $\mathrm{B}$ cells). The infiltration of these inflammatory cells has a critical role in RA as they secrete cytokines and proteinases that further degrade the extracellular matrix. Effector $\mathrm{CD} 4+\mathrm{T}$ cells play a crucial role in the disease, and RA is commonly characterized by an imbalance of Th1/Th17 and regulatory $\mathrm{T}$ (Treg) cells [10]. The combined action of these two major mechanisms promotes joint destruction and bone erosion.

\section{Premature immunosenescence in RA}

RA is associated with several features of accelerated aging, including premature immunosenescence and increased prevalence of age-related diseases. The most frequent comorbidities observed in RA patients include cardiovascular disease, malignancies, lung disease, osteoporosis, changes in body composition and neuropsychiatric diseases [11]. Immunosenescence has a special impact on the development of these co-morbidities, as they are all immune-mediated conditions. Nine biological hallmarks have been proposed for aging [12], and can be identified chronologically earlier in subjects with RA: (1) genomic instability (e.g., more DNA damage), (2) telomere shortening, (3) gene regulation (e.g., epigenetic changes), (4) loss of protein homeostasis (e.g., impaired autophagy), (5) altered nutrient sensing (e.g., decreased levels of IGF-1, FOXO, AMPK, mTOR), (6) mitochondrial dysfunction [e.g., mtDNA mutations and reactive oxygen species (ROS) generation], (7) cellular senescence (e.g., altered expression of p16-p53), (8) stem cell exhaustion (e.g., impaired generation of hematopoietic stem cells), and (9) altered intercellular communication (e.g., inflammaging) [13]. This section reviews the changes in both innate and adaptive immune system in RA that resemble those observed in healthy aging. The question whether premature immunosenescence is a primary cause of RA or secondary to the chronic inflammatory processes remains to be answered.

Premature immunosenescence in RA is established by the deterioration of the regenerative capacity of $\mathrm{T}$ cells. $\mathrm{T}$ cell precursors are produced and undergo differentiation in the thymus. The thymus reaches its maximum functional capacity during puberty, and thereafter undergoes progressive thymic involution associated with the replacement of functional thymic tissue by adipose tissue [14]. This change translates into impaired production and delivery of new naive $\mathrm{T}$ cells into the bloodstream. Thymus functional capacity can be estimated by the frequency of peripheral cells expressing T-cell receptor excision circles (TRECs). TRECs are extra-chromosomal DNA sequences that form during $\mathrm{T}$ cell receptor rearrangement (TCR) and are diluted by half at each cell division [15]. RA patients show a reduction, regardless of chronological age, in the frequency of TRECS in peripheral blood mononuclear cells (PBMCs) that provides an indirect estimate of the functional integrity of the thymus [16]. Indeed, CD4+ T cells containing TRECs were significantly reduced in RA patients and their TREC levels matched those of healthy controls 20 years older [17]. Moreover, the decreased thymic functionality results in peripheral compensatory mechanisms, such as increased homeostatic proliferation, in order to keep the T-cell compartment quantitatively intact.

RA is also associated with expansion of immune cells with advanced replicative stress. Replicative stress results from the increase in the replicative history of peripheral $\mathrm{T}$ cells (homeostatic proliferation / oligoclonal expansion) in order to compensate for the reduction in cell supply due to thymic involution. Aging is associated with a reduction in T-cell receptor diversity, loss of expression of the CD28 costimulatory molecule, and telomeric erosion. CD28 is a cell surface molecule that is required for complete $\mathrm{T}$-cell activation and proliferation. A significant expansion of CD4+CD28- and CD8 + CD28- in RA was reported many years ago [18, 19], as similarly reported in ageing studies [20]. Of note, patients with extra-articular manifestations of RA had increased frequencies of such cells [21]. The frequency of CD4 + CD28- T cells in these individuals may represent more than $50 \%$ of all circulating $\mathrm{CD} 4+\mathrm{T}$ cells [22]. Anti-TNF therapy was able to significantly reduce CD8 + CD28- $\mathrm{T}$ cells (but not $\mathrm{CD} 4+\mathrm{CD} 28-\mathrm{T}$ cells) and 
correlated with clinical response as measured by DAS28/ C-reactive protein (CRP) [23]. These are clonal expansions related to significant contractions of the T-cell repertoire. RA patients had $\sim 10$-fold contraction of their naive CD4+ T-cell repertoire as compared to agematched controls [24] - indicating that 40-50-year-old RA patients have already lost approximately $90 \%$ of their available TCRs. Furthermore, these data indicate that the remaining naïve $\mathrm{T}$ cells had to expand to 10 times larger clonal sizes in order to compensate.

Replicative stress of cells may lead to cellular senescence. The cells that have reached replicative senescence do not proliferate but remain metabolically active and acquire new inflammatory and cytotoxic characteristics. The pool of CD28- T cells includes effector-memory and terminally differentiated memory cells re-expressing CD45RA (TEMRA), which may contribute to inflammaging by secreting large amounts of interferon (IFN) $-\gamma$, TNF- $\alpha$, IL-1 $\beta$, and IL- 6 upon stimulation [25]. This mixture of cytokines has been termed the senescenceassociated secretory phenotype (SASP). In addition, it has been shown that CD28- T cells acquire NK cell receptors and have high levels of granzymes and perforins, explaining the cytotoxic potential of these cells [26]. It has been proposed that acquisition of a cytotoxic phenotype in senescent $\mathrm{T}$ cells may be compensatory for losses observed in $\mathrm{T}$ and NK cells [27]. Moreover, a recent study proposed the existence of a subset of senescent Treg cells in the peripheral environment of RA [28]. These cells were defined as CD4+CD28-Foxp3+ T cells and were positively associated with age and with clinical parameters such as disease activity and treatment. These senescent Treg cells display less suppressive capacity when compared to CD28+ Treg cells [28]. It should be noted that RA is also associated with accumulation of other senescent cells. Indeed, senescent synovial fibroblasts (p16INK4a + cells) accumulate prematurely in RA and display an enhanced inflammatory phenotype [29].

Telomeric erosion has been found to be accelerated in patients with RA, regardless of age. RA patients had increased telomere shortening in granulocytes, PBMCs and $\mathrm{CD} 4+\mathrm{T}$ cells $[17,30]$. During healthy aging, the telomeric length of peripheral lymphocytes shortens 20 $40 \mathrm{bp} /$ year. In contrast in RA, this accelerated rate represents $15 \mathrm{X}$ the value observed in age-matched healthy donors [31, 32]. Hematopoietic stem cells, granulocytes and lymphocytes are the leukocytes particularly affected in the course of the disease. Overall, the telomeres remain stable until the fourth decade of life in healthy individuals. From 41 to 65 years, a marked reduction reaches the plateau after 65 years of age. In the first forty years of life in RA, the telomeric length is significantly shorter. The faster telomere erosion observed in circulating lymphocytes of RA is due to multidimensional mechanisms including telomere shortening already present in hematopoietic progenitor cells $(\mathrm{CD} 34+)$, persistent exposure to the inflammatory environment, increased oxidative stress and homeostatic proliferation [32]. However, a recent study reported similar telomere lengths in PBMCs of RA patients (controlled or active disease) and healthy controls [33]. Telomere erosion and reduced telomerase activity in $\mathrm{CD} 4+\mathrm{T}$ cells were not affected by treatment of RA patients with methotrexate (MTX) or prednisone [17, 34]. PBMCs constitute a mixture of monocytes, B cells, NK cells and $\mathrm{T}$ cells, and the telomere erosion may be more evident in isolated CD4+ naive T cells. It is known that telomere lengths may differ per cell subset and stage of differentiation. For instance, memory B cells have relatively stable telomeres [35]. In addition to increased telomere shortening, CD4+ T cells in RA also have damaged telomeres resulting from defective activity of the DNA break repair nuclease MRE11A [36]. The MER11A ${ }^{\text {low }} \mathrm{T}$ cells are hypermotile, tissue-invasive, and arthritogenic in vivo (i.e., leading to destructive synovitis).

In gerontological studies, the human cytomegalovirus (CMV) has been shown to accelerate some features of immunosenescence, of note in promoting the expansion of senescent T cells (CD28-), implicated in the reduced T-cell repertoire [37, 38]. Persistent viral infections have long been discussed in the aetiology of several autoimmune diseases, including RA [39]. Previous reports have associated increased CMV seropositivity with expansion of CD4 + CD28- T cells in RA, multiple sclerosis (MS) and systemic lupus erythematosus (SLE) [16, 33]. The CMV-specific CD4 + CD28- T cells were found to be expanded in $\mathrm{CMV}+$ but not in CMV- RA patients [40]. Treatment with ganciclovir in CMV+ RA patients with vasculitis reduced the number of $\mathrm{CD} 4+\mathrm{CD} 28-\mathrm{T}$ cells - suggesting that these cells are driven by CMV infection [41]. Methotrexate treatment of RA has also been shown to reduce the levels of CD4 + CD28- T cells [42]. Furthermore, an association with CMV and worsen disease progression and extra-articular manifestations in RA has been reported [43, 44]. It has also been shown that RA patients exhibit CMVpp65-specific IFN- $\gamma$ production in vitro with expansion of CD28-CD8+ T cells, indicating an efficient control of latent $\mathrm{CMV}$ and regardless of current therapy [45]. It has been shown that RA patients had a multi-reactive anti-herpes IgM profile, which was associated with disease activity [46]. Also, expansions of CD28- $\mathrm{T}$ cells have also been documented in various chronic infections, including malaria [47], HIV [48] and human T-lymphotropic virus type-I (HTLV-1) [49]. More studies are necessary to explore the role of persistent infections during clinical progression in RA. 
Can early immunosenescence be detected in the preclinical phase of RA, or is it a consequence of established disease? It has been reported that healthy individuals genotyped for DRB1*04, a haplotype associated with RA, share with patients the accelerated erosion of telomeres, beginning during the second to third decades of life [30]. These data suggest that chronic inflammation may not be a principal cause of premature ageing in RA. The presence of anti-citrullinated antibodies (ACPA), rheumatoid factor (RF) and high CRP levels in some patients years before onset of clinical symptoms implies that immune responses involved in the development of RA appear very early. However, it is completely unknown whether premature immunosenescence is present in the preclinical phase (ACPA+ arthralgia) of RA. Future prospective studies should be performed to explore this possibility.

\section{Impact of early immunosenescence on clinical manifestations in RA}

The immune-senescent profile observed in RA may contribute to the development and aggravation of articular and extra-articular manifestations, which take part in disease progression (Fig. 1). The progression of RA has generally been associated with the early development of characteristics and comorbidities common with older adults. Among these, cognitive impairment, cardiovascular complications and osteoporosis stand out as the main age-related co-morbidities of RA [11].

\section{Senescent T cells may contribute to disease progression and osteoporosis}

The expansion of senescent CD28- T cells has been associated with disease severity in RA $[50,51]$. Of note, the peripheral senescent $\mathrm{CD} 4+\mathrm{T}$ cells were associated with worsening of chronic inflammatory responses due to their close relationship with Th1-type cytokine synthesis [52]. The expansion of CD28- T cell subsets is particularly marked in patients with extra-articular manifestations [21]. However, peripheral CD4+CD28- T cells and cells with the same phenotype in the joint environment may respond differently under stimulation. While circulating cells in peripheral blood produce more TNF- $\alpha$, synovial resident cells produce more IL-17, an inflammatory cytokine known to be involved with impaired joint integrity [22]. The presence of senescent cells in the periphery as well as in the rheumatoid synovium may thus contribute to the destructive systemic and pathogenic inflammatory responses. In addition to their inflammatory effects, the CD28- $\mathrm{T}$ cells have

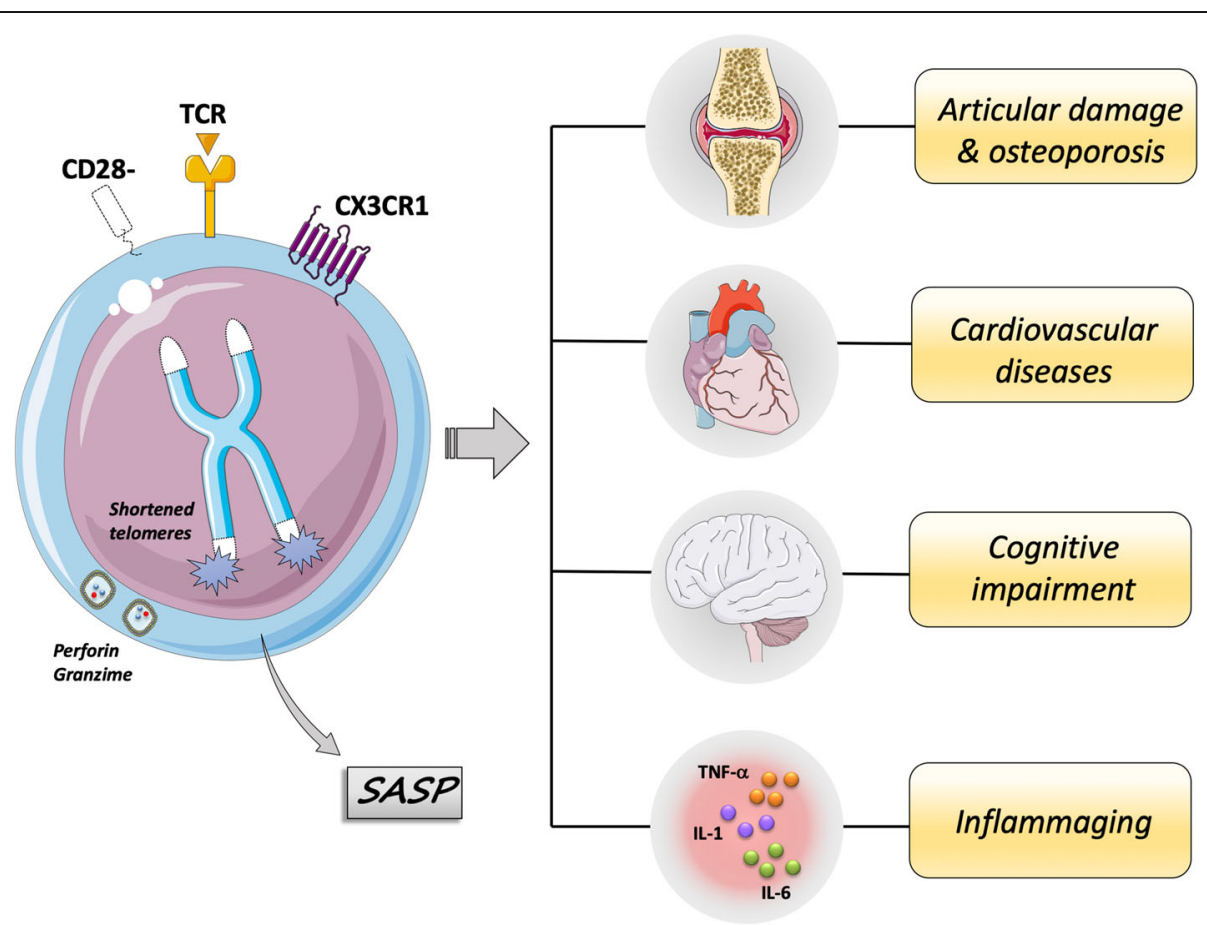

Fig. 1 The senescent T cells are associated with inflammaging and age-related morbidities in RA. The late-stage differentiated (senescent) T cells are defined by phenotypic changes including loss of CD28 expression, acquisition of inflammatory (SASP: senescence-associated secretory phenotype) and cytotoxic functions, as well as expression the chemokine receptor CX3CR1, which could underlie their ability to infiltrate peripheral inflammatory sites. These cells do not proliferate, because of shortened telomeres, but remain metabolic active. These cells have been found expanded in RA, of note during the clinical progression. They have been implicated with articular damage and osteoporosis, cardiovascular diseases and cognitive impairment 
greater expression of the chemokine receptor CX3CR1, which could underlie their ability to infiltrate peripheral inflammatory sites [53]. The ligand of CX3CR1 is fractalkine (FKN) which is expressed by fibroblast-like synoviocytes. The interaction of senescent $\mathrm{CD} 4+\mathrm{CD} 28-\mathrm{T}$ cells with synoviocytes costimulates the production of pro-inflammatory cytokines as well as the release of granules [54]. The expansion of the senescent CD4+ T cell population has been associated with increased bone loss and support of the early development of osteoporosis in RA. Indeed, CD4+CD28- T lymphocytes from RA patients exhibit higher concentrations of the receptor activator of nuclear factor kappa-B ligand (RANKL) than CD28+ cells [55]. RANKL, in combination with TNF- $\alpha$, IL- 6 and IL- $1 \beta$, acts on the differentiation of osteoclasts and degrades mineralized bone matrix through protease synthesis [56]. Therefore, the expansion of peripheral senescent $\mathrm{CD} 4+\mathrm{T}$ cells may impact bone mineral density and are negatively related to osteoporosis [55]. As previously discussed, CMV infection may worsen the clinical course and facilitate the development of extra-articular manifestations via the expansion of CD4 + CD28- T cells [39]. To date no study has investigated the impact of CMV serology on the development of osteoporosis in RA. In addition, the ACPAs and RF are associated with low bone mineral density and osteoclast-mediated bone resorption, independently of inflammation in patients with RA $[57,58]$. Of note, bone loss was identified before the clinical onset of RA in subjects with ACPAs [59].

RA patients have reduced bone mineral density as compared to age-matched controls [60]. Bone loss in RA occurs in the early stages of the disease and is intensified with increasing clinical severity. During the first two years from diagnosis, osteoporosis or osteopenia is present in 11 and $24.7 \%$ of individuals with rheumatoid arthritis, respectively [61]. Many factors inherent to the immunopathology and therapy of RA are candidate risk factors for the development of osteoporosis. Among these, the use of glucocorticoids, reduced physical activity, high disease activity and high titres of autoantibodies (RF and ACPAs) stand out in the pathological scenario of osteoporosis in RA $[60,61]$. These risk factors affect the balance between bone matrix formation and degradation, promoting resorption rates, which in turn result in osteoporosis.

\section{Cardiovascular events linked with inflammaging and senescent $T$ cells}

Mounting evidence indicates that chronic inflammation is a major risk factor for development of cardiovascular complications in the elderly as well as in adults with RA [62-64]. RA patients are at high risk of developing early cardiovascular complications $[50,65]$. The risk rate for coronary artery disease and myocardial infarction in patients with RA is $2-3$ times higher and can be identified even in the early stages of the disease. These risk rates are similar to those presented by subjects without RA but 10 years older [11, 62]. The increased risk of cardiovascular morbidity in RA can be explained by (1) the chronic systemic inflammation, (2) the modulating effect that RA has on traditional cardiovascular risk factors (e.g., hypertension, smoking, dyslipidemia and obesity), and (3) the use of specific medications, including nonsteroidal anti-inflammatory drugs, glucocorticoids, and disease modifying anti-rheumatic drugs [11]. Longitudinal studies have shown a tendency to reduce cardiovascular risk with improved disease activity [65].

The healthy heart contains several leukocytes, including macrophages, neutrophils, $\mathrm{B}$ cells, and $\mathrm{T}$ cells. The role of cardioimmunology in cardiac homeostasis and disease can be found in a recent comprehensive review [66]. Perturbations in cellular composition or functionality changes in the heart as well as in the atherosclerotic plaque may thus contribute do the onset and progression of cardiovascular diseases. Several studies have linked cardiovascular disease with increasing senescent CD28- T cells. Of note, the CD4 + CD28- T cells have been found expanded in subjects with angina, acute coronary syndrome, myocardial infarction, chronic heart failure and abdominal aortic aneurysms [67-72].

$\mathrm{CMV}$ and $\mathrm{CMV}$-specific $\mathrm{T}$ cells are also involved in cardiovascular disease [44]. CMV has been associated with cardiovascular disease since it was isolated from atherosclerotic lesions, although it was largely unknown whether it played a causative role [73]. It has also been shown that mice infected with murine CMV (MCMV) developed hypertension within weeks, independently of atherosclerotic plaque formation, resulting from persistent CMV infection of vascular endothelial cells (EC) [74]. CMV leads to the development of CD4 + CD28- T cells with cytotoxic features targeting the vascular endothelium [75]. Because inflammaging plays an important role in the pathology of cardiovascular disease, CMV may also play a direct role in skewing inflammatory responses. There is some evidence supporting this premise. It has been shown that CMV may induce the production of prostaglandin E2 (PGE2) in human fibroblasts and the CMV envelope glycoprotein $(\mathrm{gB})$ upregulates the expression of NF- $\mathrm{kB}$, a key transcription factor for genes encoding inflammatory mediators [76]. Therefore, $\mathrm{CMV}$ has both direct and indirect roles (i.e., through the expansion of cytotoxic CD28- T cells) in promoting cardiovascular disease.

Telomere shortening is also associated with comorbidities related to extra-articular manifestations. Increased telomere attrition was shown in $\mathrm{T}$ cells from patients with atherosclerosis and senescent $\mathrm{T}$ cells were 
also reported to be important in hypertension [77]. Telomeric erosion is related to the development of atherosclerotic plaque and cardiovascular disease in individuals with RA [78]. Also, the shortening of the terminal portions of chromosomes is associated with increased reactivity to self-antigens and loss of immunological tolerance, thus it has been suggested as a possible risk factor for the development of RA [79]. However, it remains to be established how senescent $\mathrm{T}$ cells are regulated and contribute to the pathogenesis of cardiovascular diseases. It is speculated that increased numbers of senescent $\mathrm{T}$ cells with cytotoxic and proinflammatory features may directly contribute to cardiovascular disease.

\section{Cognitive impairment, depression and anxiety}

Patients with RA, in active disease or in remission, have significant impairment of cognitive functions in several cognitive dimensions as compared to controls. These include deficits in attention and working memory, processing speed and executive functions, inhibitory functions, and verbal declarative memory $[19,80]$. The impairment in cognitive functions is profound and performance of RA patients is reduced to $50 \%$ of that observed in agematched healthy controls. The cognitive impairment was found worsen in patients with active disease as compared with those in remission [80]. Interestingly, cognitive impairment is related to changes in plasma neurotrophins, which are closely involved in cognition and neuroplasticity. Cognitive impairment has also been correlated with more functional limitations, depression and pain in RA patients. Potential risk factors for cognitive impairment are educational level, low income, oral glucocorticoid use and presence of cardiovascular disease [11]. However, previous studies found no associations between cognitive impairment and glucocorticoid use in RA [80-82].

Several mechanisms are potentially involved with cognitive dysfunction in RA. One mechanism is persistent inflammation, which is known to contribute to cognitive decline during healthy aging [83-85]. Another potential mechanism involves the expansion of senescent immune (and non-immune) cells in RA. In particular, it has been shown that the increasing population of senescent CD8 + CD28- T cells was negatively correlated with the memory functions of RA patients [19]. In contrast, RA patients with higher amounts of memory $\mathrm{T}$ cells $(\mathrm{CD} 45 \mathrm{RO}+)$ had better cognitive function. This finding is in agreement with the fact that cerebrospinal fluid of healthy adults contains large amounts of memory $\mathrm{CD} 45 \mathrm{RO}+\mathrm{T}$ cells [86]. CMV infection may interact (indirectly) with cognitive functions in RA through the expansion of CD28- $\mathrm{T}$ cells, albeit no study has investigated this interaction. There is a growing interest in the role of infectious agents in the pathogenesis of dementia, but evidence is scarce. A recent meta-analysis explored the effect of any of eight human herpesviruses on development of dementia or mild cognitive impairment (MCI) [87]. Recent infection or reactivation of herpes simplex virus type 1 or type $1 / 2$ unspecified, CMV and human herpes virus- 6 was associated with dementia or MCI, though results were inconsistent across studies.

Circulating autoantibodies may also contribute to poor cognition in RA. It has been shown that RA patients in remission had increased levels of autoantibodies targeting brain antigens, such as myelin basic protein and myelin oligodendrocyte glycoprotein, which inversely correlated with cognitive tests [88]. The same study reported increased plasma levels of central nervous system (CNS)-restricted proteins $(\mathrm{S} 100 \beta)$ in RA, indicating a dysfunctional blood brain barrier (BBB). CNS antibodies are normally restricted to the brain parenchyma. However, increased BBB permeability is frequently observed in chronic inflammatory disorders (including RA) and may thus facilitate the influx of circulating molecules [89]. Increased plasma levels of CNS autoantibodies have also been found in Systemic Lupus Erythematosus and Sjogren's syndrome, and also associated with poor cognition. The cognitive impairment in RA could be thus explained by the detrimental action of CNS autoantibodies, as suggested by demyelination observed in some RA patients [90]. However, further studies are necessary to investigate to what extent these autoantibodies are related to premature senescence in RA.

Depression and anxiety are also common in RA and associated with worsening disease progression [91]. Also, the presence of depression can aggravate responses to disease-modifying interventions including biological therapies [92]. Mood swings, irritability and panic attacks are frequently reported in autoimmune disorders. The prevalence of depression is considerably higher in RA. A meta-analysis that included 13,189 patients from 72 studies revealed that the prevalence of major depression is nearly $3 \mathrm{X}$ higher than expected in the general population [93]. Several clinical trials using monoclonal antibodies (TNF or IL-6 inhibitors) to treat RA resulted in significant antidepressant effects [94]. Indeed, persistent inflammation could be one of the potential mechanisms involved with depression in RA, as solid evidence indicates that pro-inflammatory mediators change key brain areas involved with cognition and mood [95]. Also, it is tempting to speculate that peripheral activated $\mathrm{CD} 4+\mathrm{T}$ cells may promote anxiety behaviour in RA. As discussed below, stress-induced xanthine by peripheral $\mathrm{CD} 4+\mathrm{T}$ cells is capable to induce anxiety-like behaviour in mice [96]. Patients with RA have increased serum xanthine levels [96] - and those with the highest levels had good responses to anti-TNF- $\alpha$ therapy [97]. Given 
that TNF is produced at high levels by RA T cells [98], this pathway is possibly involved in the immune-to-brain communication and in the generation of anxiety behaviour. It remains to be established whether senescent immune cells are contributing to depression in RA. One study reported an accumulation of peripheral senescent $\mathrm{T}$ cells $(\mathrm{CD} 57+\mathrm{CD} 28-)$ in older hip fracture patients who developed depressive symptoms [99]. These data indicate that onset of depression after a hip fracture in older adults is an important driver of immune dysregulation. It will be discussed in the next section how plasma inflammatory mediators and peripheral immune cells influence complex human behaviors, impairing cognitive functions and leading to depression.

\section{The pathways of immune-to-brain communication}

Peripheral immune cells and derived molecules crosstalk to the brain during physiological and pathological processes, modulating key brain processes involved with cognition, mood and social behaviour. This cross talk is established by three pathways: the humoral, neural and cellular (leukocyte) routes (Fig. 2). In the humoral route, inflammatory mediators (i.e., cytokines) reach the brain directly or indirectly through the bloodstream. In the neural route, inflammatory molecules and damageassociated molecules, which are in close contact with peripheral innervation in inflamed tissues, lead to brain changes via activation of afferent neuronal pathways. Finally, circulating leukocytes (mostly $\mathrm{T}$ cells and monocytes) secrete cytokines into the cerebral tissue at the brain borders and therefore also interfere with brain processes.

\section{The humoral pathway of immune-to-brain communication}

The "sickness behaviour" is the prototype of humoral pathways for neuro-immune communication. Following an infection, the organism rapidly starts a set of changes to enhance survival. This set of changes may include sickness behaviour, as shown by physiological (e.g., fever, blood composition changes), behavioural (e.g., decreased locomotion, food and water intake) and hormonal changes (e.g., secretion of hormones from the hypothalamic-pituitary-adrenal, HPA, axis). This "sickness behaviour" is then a proxy for a depressive state observed in an acutely ill animal or person. For instance,

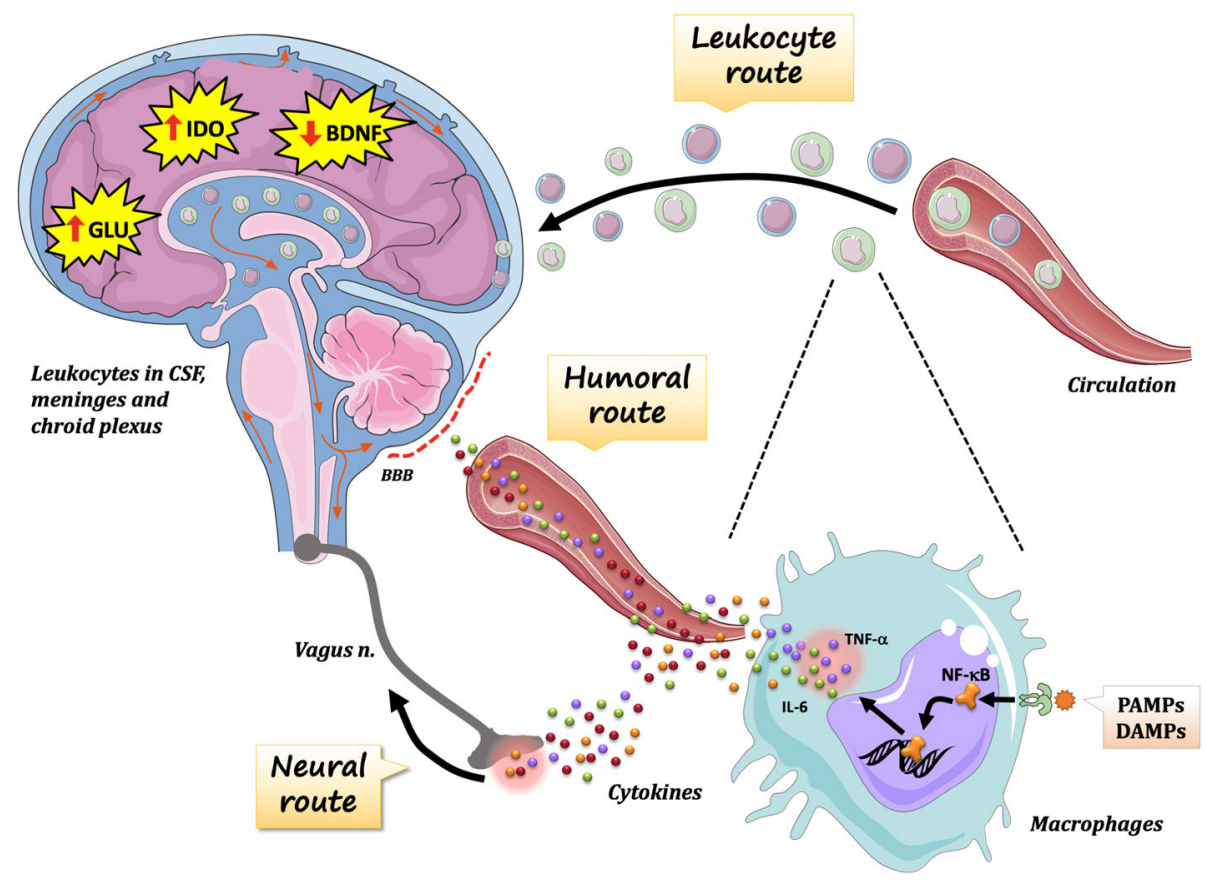

Fig. 2 Pathways involved in the immune-to-brain communication. Three pathways participate in the immune-to-brain communication: humoral, neural and cellular (leukocyte) routes. Tissue-resident macrophages get activated by pathogen-associated molecular patterns (PAMPs) or damageassociated molecular patterns (DAMPs). Both PAMPs (infections) and DAMPs (sterile injury) engage inflammatory signalling pathways, such as nuclear factor-kB (NF-kB). The pro-inflammatory cytokines in turn are promptly secreted and enter the bloodstream. The plasma cytokines can reach the brain through various mechanisms, including the i) active transport by crossing the brain-blood barrier (BBB) through leaky areas in the circumventricular organs (humoral route); or ii) through the activation of afferent neural pathways (e.g., the vagus nerve). The leukocytic route is another mechanism of immune-to-brain communication and is mediated by the migration of circulating leukocytes to the brain borders. Leukocytes are present in small numbers in brain circumventricular organs and choroid plexus. Under healthy conditions, these peripheral immune cells support neuronal function and scan the brain for pathogens or tissue damage 
the set of behaviours observed during the febrile state include depressed mood, impaired cognition, apathy, and irritability - all of which are core symptoms of major depressive disorder. The expression "sickness behaviour" is also manifested in the context of an existing chronic low-grade inflammation as observed in different neuropsychiatric disorders, including major depression, bipolar disorder, and schizophrenia [100]. Sickness behaviour is thus critically related to peripheral proinflammatory cytokines.

The increasing levels of plasma pro-inflammatory cytokines observed in RA may directly trigger changes in CNS functions. Plasma cytokines may gain access to the brain via saturable transporters at the blood-brain barrier (BBB) [101]. The "sickness behaviour" can be induced by administration of pro-inflammatory cytokines, or endotoxin. IL-1 $\beta$ and TNF- $\alpha$ are the main cytokines involved in triggering it. In rodents, both systemic and intracerebral administration of IL-1 $\beta$ or TNF- $\alpha$ results in signs of sickness behaviour in a time- and dose-dependent manner. Furthermore, IL-6deficient mice have attenuated signs of LPS-induced sickness behaviour as compared with wild-type animals, indicating that IL-6 expression in the brain may contribute to the expression of other cytokines (including $\mathrm{IL}-1 \beta$ and TNF- $\alpha$ ) following immune challenges [101].

How do pro-inflammatory cytokines promote depressive behaviour? The underlying mechanisms involve changes in brain monoamine levels (i.e., dopamine and serotonin), excitotoxicity (i.e., increased glutamate levels) and reduced neuroplasticity. Pro-inflammatory cytokines may reduce brain levels of serotonin, an important neurochemistry alteration in depression and target of some antidepressants. Both experimental studies and clinical trials have indicated that the decrease serotonin levels was highly correlated with the development of cytokine-induced depressive symptoms. Previous studies investigating the effects of IFN- $\alpha$ upon indolamine 2,3 dioxygenase (IDO) pathway provided further evidence that the serotonin pathway is influenced by pro-inflammatory cytokines. IDO is involved in breaking down tryptophan into kynurenine. It is expressed in the brain, and is highly inducible by proinflammatory cytokines. Under inflammatory conditions, tryptophan availability for serotonin synthesis decreases, while kynurenine levels increase due to an enhanced IDO activity [101]. Moreover, kynurenine easily crosses the blood brain barrier (BBB) and enters the brain, where it is metabolized by glial cells into 3-hydroxykynurenine (3HK), quinolinic acid (QA), kynurenic acid (KA). 3Hydroxykynurenine is an oxidative stressor, whereas QA is an N-methyl-D-aspartate (NMDA) receptor agonist, stimulating glutamate release and blocking glutamate reuptake by astrocytes [102]. Quinolinic acid is also associated with lipid peroxidation and oxidative stress. Taken together, these activities may lead to excitotoxicity and neurodegeneration (key features of mood disorders). In contrast to QA, KA can reduce glutamate and dopamine release, which in turn can contribute to cognitive dysfunction [102]. Increased levels of QA have been found in the brain of suicide victims with depression [103]. Moreover, the binding of glutamate to extrasynaptic NMDA receptors may lead to decreased levels of brain-derived neurotrophic factor (BDNF), impairing neuroplasticity (essential to cognition) [104]. BDNF is crucially involved in neurogenesis, essential for an antidepressant response, and has been shown to be reduced by TNF- $\alpha$ and IL- $1 \beta$ [105]. It has been suggested that neuroinflammation, as observed during ageing or chronic inflammatory diseases, may degrade the BDNF levels needed to maintain cognitiverelated plasticity processes at hippocampal synapses [106]. Indeed, previous preclinical studies reported detrimental effects of inflammation on BDNF expression in the brain [107].

Is there any evidence that neurotrophins are altered in RA? In a recent study, RA patients (of note those with active disease) had increased plasma levels of BDNF [80]. Although this finding seems in contrast to what is expected for patients with chronic inflammation, it should be noted that most of the circulating BDNF is likely derived from a leukocyte source in inflammatory disorders. Indeed, previous studies reported increased BDNF levels in RA and Lupus [108]. In addition, it has been demonstrated that PBMCs and synovial cells constitutively express BDNF [109]. However, poor cognition in RA patients was associated with lower plasma levels of glial cell line-derived neurotrophic factor (GDNF). Because GNDF is only produced in the CNS [110], lower levels of this neurotrophin may better predict poor memory performance than BDNF.

\section{The neural pathway of immune-to-brain communication}

Peripheral sensory neurons are found in close proximity to immune cells, and are capable of carrying afferent immune-related signals to the brain via the spinal cord (sympathetic) and vagus nerve (parasympathetic) [105]. The afferent pathway of this communication includes vagal stimulation by inflammatory cytokines, enabling an unconscious representation in the CNS of peripheral inflammation [111]. In this context, the immune system would be acting as a "sensory organ", a concept originally proposed by J. Edwin Blalock during the 1980's [112]. The afferent vagus nerve ends primarily in the brainstem medulla. It is then communicated to other brainstem nuclei and forebrain regions associated with integration of visceral sensory information as well as coordinating of autonomic functions and behavioural responses [113].

Moreover, the efferent vagus nerve is known to modulate the immune system - of note inflammation. 
Although the efferent arc of the vagus nerve does not directly communicate with lymphoid organs [105], its cholinergic stimulation via acetylcholine $(\mathrm{ACh})$ secretion suppresses excessive inflammation in the heart, liver, pancreas and gastrointestinal tract [113]. The efferent arc of the vagal-immune communication is part of the "inflammatory reflex" [114]. It has been shown that signals from the efferent vagus reach the splenic nerve, which induce the release of ACh by a splenic T-cell subset with important anti-inflammatory actions [115]. Interestingly, in nude mice (i.e., lacking $\mathrm{T}$ cells) vagal stimulation cannot restrain the inflammatory response. However, the transfer of ACh-producing T cells, repopulating the spleen in nude mice, restores the integrity of this anti-inflammatory neural circuit [115].

Preclinical studies have been performed to explore the efferent arm of the inflammatory reflex in controlling acute and chronic inflammation. The efferent pathway of the inflammatory reflex is responsible for attenuating TNF- $\alpha$ levels during septic shock. Accordingly, a range of sickness responses was abolished by cutting the vagus nerve, including fever, decreased food-motivated behaviour, increased sleep, decreased activity, decreased social interaction, changes in brain activity, and release of stress hormones [116]. ACh interacts with nicotinic receptors $(\alpha 7)$, expressed by several types of leukocytes, and the intracellular pathways of this regulation have already been elucidated [117]. Clinical studies have also indicated that innate immune responses (inflammation) are under vagal control. Previous studies with healthy adults revealed that systemic low-grade inflammation (i.e., increased plasma CRP and IL-6) was associated with reduced vagus nerve activity $[118,119]$. There is also increasing evidence that vagal control is impaired during chronic inflammatory conditions. Indeed, the association of reduced vagal activity and increased inflammatory responses has been demonstrated in a range of chronic inflammatory diseases, including arthritis, lupus and inflammatory bowel disease [120-122]. Based on these data, clinical trials with electrical stimulation of the vagus nerve, through pacemaker-like devices, have yielded positive results in controlling chronic inflammation. Indeed, electrical vagal stimulation (up to four times daily) inhibited TNF- $\alpha$ production for up to 84 days and attenuated disease severity in RA [123].

\section{The cellular pathway of immune-to-brain communication} Circulating leukocytes, including senescent cells, may also be contributing to cognitive impairment, depression and anxiety reported in RA. The cellular (leukocyte) pathway is a known axis of immune-to-brain communication and includes leukocytes present in small numbers in brain vasculature, choroid plexus and meninges. Under healthy conditions, these immune cells support neuronal functions and may also scan the brain for pathogens or tissue damage [124]. It should be noted that under healthy conditions leukocytes are not found in the cerebral parenchyma. The recruitment of blood monocytes to the brain has been widely reported in classical inflammatory conditions, such as neurotrauma and neuroinfection. This monocyte trafficking into the brain is required for inducing anxiety-like behaviour after neurophatic pain [125], and cognitive impairment following peripheral surgery [126]. Mnocyte migration to the brain was also observed following psychosocial stress [127], and associated with prolonged anxiety behaviour after stress. The accelerated senescence observed in RA could also be involved in brain changes associated with neuroinflammation. Immunosenescence and inflammaging may induce neuroinflammation by modulating glial cells (e.g., microglia) towards a more pro-inflammatory state (M1-like), leading to dysfunctional neural changes and accumulation of brain tissue damage $[106,128]$.

Peripheral lymphocytes have key roles in regulating healthy brain functions, including responses to psychosocial stress [129], spatial learning and memory [130] and adult neurogenesis in rodents [131]. Of note, autoreactive CD4+ $\mathrm{T}$ cells have been implicated in the regulation of cognitive processes and mice deficient in $\mathrm{T}$ cells are cognitively impaired [131, 132]. The pro-cognitive properties of $\mathrm{T}$ cells have been associated with increased production of IL-4, IFN- $\gamma$ and IL-17 at brain borders [133-135]. These cytokines were shown to improve learning behaviour via the upregulation of BDNF expression by neural cells. In addition, it has been shown that CD4+ T cells with defective mitochondria lead to stress-induced anxiety behaviour in mice through the release of xanthine [96]. Patients with anxiety had higher serum xanthine levels than healthy controls. Also, it was shown that $\mathrm{T}$ cell-derived xanthine has specific action on oligodendrocytes in the left amygdala, a key brain area involved with stress and anxiety. Interestingly, the mitochondrial pattern observed in these stressexposed CD4+ T cells is similarly observed in RA CD4+ T cells [136]. These data highlight the importance of secreted products of peripheral CD4+ T cells for the maintenance of cognitive and stress-related functions. In addition, it has been shown that $\mathrm{CD} 4+\mathrm{T}$ cells expressing the T-box transcription factor Eomesodermin (EOMES) have cytotoxic features and are essential for chronic neuroinflammation observed in experimental autoimmune encephalomyelitis (EAE) [137]. These EOMES+CD4+ T cells were found to be increased in the peripheral blood and cerebrospinal fluid from patients with multiple sclerosis. These cells may be also relevant for the pathogenesis of RA, as EOMES+CD4+ $\mathrm{T}$ cells were found expanded in the synovial fluid of RA patients [138]. It remains to be investigated whether these cells modulate cognitive functions in RA.

Senescent CD28- T cells may be also implicated in modulating cognitive processes, as expansion of this 
subset has been associated with cognitive impairment in RA $[19,80]$. The expansion of CD28- T cells has been also reported in neuropsychiatric disorders associated with cognitive impairment, including bipolar disorder, early-life stress, and Alzheimer's disease [139, 140]. Indeed, patients with mild cognitive impairment or Alzheimer's disease had increased expansion of latedifferentiated T cells (CD28-) [141, 142]. These data further support the role of peripheral lymphocytes in human cognition. Although the underlying mechanisms by which senescent $\mathrm{T}$ cells modulate brain processes were not elucidated, it is tempting to speculate it could be related to their pro-inflammatory phenotype.

\section{Conclusions}

In this review, I have attempted to give a perspective on key aspects of accelerated ageing in RA. The hallmarks of ageing can be identified prematurely in RA and clinical progression is associated with development of agerelated co-morbidities. Patients with RA also show several signatures of accelerated immune ageing, of note in ageing $\mathrm{T}$ cells. Briefly, immunosenescence is characterized by the profound thymic involution, enhanced telomere erosion, defective telomerase activity, increased CMV seropositivity, contraction of the T-cell repertoire and accumulation of late-stage differentiated $\mathrm{T}$ cells (CD28-). The question whether premature immunosenescence is a primary cause of RA or secondary to chronic inflammatory processes remains to be answered. More prospective studies should be performed to study immunosenescence in preclinical RA and to explore the association with RA severity and development of extraarticular manifestations.

Osteoporosis, cardiovascular complications and cognitive impairment stand out as the main age-related comorbidities of RA. Immune cells participate actively in the healthy physiology of articular, cardiovascular and brain tissues. Changes in the immune cells taking part in the peripheral tissues (including the brain) have thus been implicated in pathological processes. Indeed, senescent $\mathrm{T}$ cells have been associated with disease progression and development of age-related diseases in RA as they have pro-inflammatory (i.e., SASP) and cytotoxic phenotypes as well as displaying enhanced ability to infiltrate into inflammatory tissues. Senescent $\mathrm{T}$ cells, chronic inflammation and autoantibodies targeting CNS antigens have been associated with poor cognition in RA. There is some evidence that CMV may be involved in the clinical manifestations in RA, of note in cardiovascular disease. Finally, this article reviews data supporting the hypothesis that peripheral immune cells and derived molecules cross-talk to the brain, and modulate key processes involved with cognition, mood and social behaviour. This cross talk is established by three pathways: the humoral, neural and leukocyte routes. Hence, the removal of senescent immune cells by new therapies should improve clinical progression in RA.

\section{Abbreviations \\ ACh: Acetylcholine; ACPAs: Anti-citrullinated protein antibodies; BBB: Blood brain barrier; BDNF: Brain-derived neurotrophic factor; CMV: Cytomegalovirus; CNS: Central nervous system; CRP: C-reactive protein; DAMPs: Damage- associated molecular patterns; FKN: Fractalkine; GDNF: Glial cell line-derived neurotrophic factor; HLA: Human leukocyte antigen; IL: Interleukin; MMPs: Metaloproteinases; MTX: Methotrexate; NK: Natural killer; \\ PBMCs: Peripheral blood mononuclear cells; RA: Rheumatoid arthritis; RANKL: Receptor activator of nuclear factor kappa-B ligand; RF: Rheumatoid factor; SASP: Senescence-associated secretory phenotype; TEMRA: Terminally differentiated memory cells re-expressing CD45RA; TNF: Tumour necrosis factor; TRECs: T-cell receptor excision circles; Treg: Regulatory $T$}

\section{Acknowledgements}

The figures were designed using elements from Smart Servier medical art that are licensed under creative commons 3.0 terms.

\section{Author's contributions}

The author read and approved the final manuscript.

\section{Funding}

This article was supported by grants from Conselho Nacional de Desenvolvimento Científico e Tecnológico (CNPq), Fundação de Amparo à Pesquisa do Rio Grande do Sul (FAPERGS), and Coordenação de Aperfeiçoamento de Pessoal de Nível Superior - Brasil (CAPES - Finance Code 001).

\section{Availability of data and materials}

Not applicable.

Ethics approval and consent to participate

Not applicable.

\section{Consent for publication}

Not applicable.

\section{Competing interests}

The author declares that he has no competing interests.

Received: 25 December 2019 Accepted: 4 March 2020

Published online: 09 March 2020

\section{References}

1. Smolen JS, Aletaha D, Barton A, Burmester GR, Emery P, Firestein GS, et al. Primer arthritis rheumatoid. Nat Rev Dis Prim. 2018;4:1-23. https://doi.org/ 10.1038/nrdp.2018.1

2. Mclnnes IB, Schett G. The pathogenesis of rheumatoid arthritis. N Engl J Med. 2011;365:2205-19. https://doi.org/10.1056/nejmra1004965.

3. Prete M, Racanelli V, Digiglio L, Vacca A, Dammacco F, Perosa F. Extraarticular manifestations of rheumatoid arthritis: An update. Autoimmun Rev. 2011;1:123-31. https://doi.org/10.1016/j.autrev.2011.09.001.

4. Londei M, Savill CM, Verhoef A, Brennan F, Leech ZA, Duance V, et al. Persistence of collagen type II-specific T-cell clones in the synovial membrane of a patient with rheumatoid arthritis. Proc Natl Acad Sci U S A. 1989;86:636-40. https://doi.org/10.1073/pnas.86.2.636.

5. Glant TT, Mikecz K, Arzoumanian A, Poole AR. Proteoglycan-induced arthritis in balb/c mice. Arthritis Rheum. 1987;30:201-12. https://doi.org/10.1002/art. 1780300211.

6. Verheijden GFM, Rijnders AWM, Bos E, Coenen-De Roo CJJ, Van Staveren CJ, Miltenburg AMM, et al. Human cartilage glycoprotein-39 as a candidate autoantigen in rheumatoid arthritis. Arthritis Rheum. 1997;40:1115-25. https://doi.org/10.1002/art.1780400616.

7. Gregersen PK, Silver J, Winchester RJ. The shared epitope hypothesis. An approach to understanding the molecular genetics of susceptibility to rheumatoid arthritis. Arthritis Rheum. 1987:30:1205-13. https://doi.org/10. 1002/art.1780301102. 
8. Wang D, Zhang J, Lau J, Wang S, Taneja V, Matteson EL, et al. Mechanisms of lung disease development in rheumatoid arthritis. Nat Rev Rheumatol. 2019;15:581-96. https://doi.org/10.1038/s41584-019-0275-x.

9. Holmdahl R, Malmström V, Burkhardt $H$. Autoimmune priming, tissue attack and chronic inflammation - the three stages of rheumatoid arthritis. Eur J Immunol. 2014;44:1593-9. https://doi.org/10.1002/eji.201444486.

10. Burmester GR, Feist $E$, Dörner T. Emerging cell and cytokine targets in rheumatoid arthritis. Nat Rev Rheumatol. 2013;10:77-88. https://doi.org/10. 1038/nrrheum.2013.168.

11. van Onna M, Boonen A. The challenging interplay between rheumatoid arthritis, ageing and comorbidities. BMC Musculoskelet Disord. 2016;17:184 https://doi.org/10.1186/s12891-016-1038-3.

12. López-Otín C, Blasco MA, Partridge L, Serrano M, Kroemer G. The hallmarks of aging. Cell. 2013;153:1194-217. https://doi.org/10.1016/j.cell.2013.05.039.

13. Chalan P, Van Den Berg A, Kroesen B-J, Brouwer L, Boots A. Rheumatoid arthritis, Immunosenescence and the hallmarks of aging. Curr Aging Sci. 2015:8:131-46.

14. Kirokawa K, Makinodan T. Thymic involution: effect on T cell differentiation. J Immunol. 1975;114:1659-64

15. Goronzy JJ, Shao L, Weyand CM. Immune aging and rheumatoid arthritis. Rheum Dis Clin N Am. 2010;36:297-310. https://doi.org/10.1016/j.rdc.2010. 03.001.

16. Thewissen $M$, Somers $V$, Venken $K$, Linsen $L$, van Paassen $P$, Geusens $P$, et al. Analyses of immunosenescent markers in patients with autoimmune disease. Clin Immunol. 2007;123:209-18. https://doi.org/10.1016/j.clim.2007. 01.005.

17. Koetz K, Bryl E, Spickschen K, O'Fallon WM, Goronzy JJ, Weyand CM. T cell homeostasis in patients with rheumatoid arthritis. Proc Natl Acad Sci U S A. 2000;97:9203-8. https://doi.org/10.1073/pnas.97.16.9203.

18. Pawlik A, Ostanek L, Brzosko I, Brzosko M, Masiuk M, Machalinski B, et al. The expansion of CD4+CD28- T cells in patients with rheumatoid arthritis. Arthritis Res Ther. 2003;5. https://doi.org/10.1186/ar766.

19. Petersen LE, Grassi-Oliveira R, Siara T, Ribeiro dos Santos SG, Itha M, de Nardi $T$, et al. Premature Immunosenescence is associated with memory dysfunction in rheumatoid arthritis. Neuroimmunomodulation. 2015;22:1307. https://doi.org/10.1159/000358437.

20. Effros RB, Dagarag M, Spaulding C, Man J. The role of CD8+ T-cell replicative senescence in human aging. Immunol Rev. 2005;205:147-57.

21. Martens PB, Goronzy JJ, Schaid D, Weyand CM. Expansion of unusual CD4+ T cells in severe rheumatoid arthritis. Arthritis Rheum. 1997:40:1106-14. https://doi.org/10.1002/art.1780400615.

22. Pieper J, Johansson S, Snir O, Linton L, Rieck M, Buckner JH, et al. Peripheral and site-specific CD4(+) CD28(null) T cells from rheumatoid arthritis patients show distinct characteristics. Scand J Immunol. 2014;79:149-55. https://doi. org/10.1111/sji.12139.

23. Scarsi M, Ziglioli T, Airo P. Decreased circulating CD28-negative T cells in patients with rheumatoid arthritis treated with abatacept are correlated with clinical response. J Rheumatol. 2010;37:911-6. https://doi.org/10.3899/ jrheum.091176.

24. Wagner UG, Koetz K, Weyand CM, Goronzy JJ. Perturbation of the T cell repertoire in rheumatoid arthritis. Proc Natl Acad Sci U S A. 1998;95:1444752. https://doi.org/10.1073/pnas.95.24.14447

25. Sallusto F, Lenig D, Forster R, Lipp M, Lanzavecchia A. Two subsets of memory T lymphocytes with distinct homing potentials and effector functions. Nature. 1999;401:708-12. https://doi.org/10.1038/44385.

26. Fann M, Chiu WK, Wood WH, Levine BL, Becker KG, Weng N-P. Gene expression characteristics of CD28null memory phenotype CD8+ T cells and its implication in T-cell aging. Immunol Rev. 2005;205:190-206. https://doi. org/10.1111/j.0105-2896.2005.00262.x.

27. Vallejo AN, Mueller RG, Hamel DL, Way A, Dvergsten JA, Griffin P, et al. Expansions of NK-like_ T cells with chronologic aging : Novel lymphocyte effectors that compensate for functional deficits of conventional NK cells and T cells. 2011;10:354-61. https://doi.org/10.1016/j. arr.2010.09.006.

28. Fessler J, Raicht A, Husic R, Ficjan A, Schwarz C, Duftner C, et al. Novel senescent regulatory $T$-cell subset with impaired suppressive function in rheumatoid arthritis. Front Immunol. 2017:8:1-11. https://doi.org/10.3389/ fimmu.2017.00300.

29. Del Rey MJ, Valín Á, Usategui A, Ergueta S, Martín E, Municio C, et al. Senescent synovial fibroblasts accumulate prematurely in rheumatoid arthritis tissues and display an enhanced inflammatory phenotype. Immun Ageing. 2019;16:1-9. https://doi.org/10.1186/s12979-019-0169-4.

30. Schönland SO, Lopez C, Widmann T, Zimmer J, Bryl E, Goronzy JJ, et al. Premature telomeric loss in rheumatoid arthritis is genetically determined and involves both myeloid and lymphoid cell lineages. Proc Natl Acad Sci U S A. 2003. https://doi.org/10.1073/pnas.2233561100.

31. Steer SE, Williams FMK, Kato B, Gardner JP, Norman PJ, Hall MA, et al. Reduced telomere length in rheumatoid arthritis is independent of disease activity and duration. Ann Rheum Dis. 2006;66:476-80. https://doi.org/10. 1136/ard.2006.059188

32. Costenbader KH, Prescott J, Zee RY, De Vivo I. Immunosenescence and rheumatoid arthritis: does telomere shortening predict impending disease? Autoimmun Rev. 2011;10:569-73. https://doi.org/10.1016/j.autrev.2011.04. 034.

33. Petersen LE, Schuch JB, de Azeredo LA, Baptista TSA, Motta JG, Do Prado $A D$, et al. Characterization of senescence biomarkers in rheumatoid arthritis: relevance to disease progression. Clin Rheumatol. 2019;38:2909-15. https:// doi.org/10.1007/s10067-019-04615-0.

34. Fujii H, Shao L, Colmegna I, Goronzy JJ, Yand CM. Telomerase insufficiency in rheumatoid arthritis. Proc Natl Acad Sci U S A. 2009;106:4360-5. https:// doi.org/10.1073/pnas.0811332106.

35. Weng NP, Granger L, Hodes RJ. Telomere lengthening and telomerase activation during human B cell differentiation. Proc Natl Acad Sci U S A. 1997;94:10827-32. https://doi.org/10.1073/pnas.94.20.10827.

36. Li Y, Shen Y, Hohensinner P, Ju J, Wen Z, Goodman SB, et al. Deficient activity of the nuclease MRE11A induces T cell aging and promotes Arthritogenic effector functions in patients with rheumatoid arthritis. Immunity. 2016;45:903-16. https://doi.org/10.1016/j.immuni.2016.09.013.

37. Koch S, Larbi A, Özcelik D, Solana R, Gouttefangeas C, Attig S, et al. Cytomegalovirus infection: A driving force in human T cell immunosenescence. Ann N Y Acad Sci. 2007;1114:23-35. https://doi.org/10. 1196/annals.1396.043.

38. Luz Correa B, Ornaghi AP, Cerutti Muller G, Engroff P, Pestana Lopes R, Gomes Da Silva Filho I, et al. The inverted CD4:CD8 ratio is associated with cytomegalovirus, poor cognitive and functional states in older adults. Neuroimmunomodulation. 2014:21:206-12. https://doi.org/10.1159/ 000356827.

39. Bano A, Pera A, Almoukayed A, Clarke THS, Kirmani S, Davies KA, et al. CD28null CD4 T-cell expansions in autoimmune disease suggest a link with cytomegalovirus infection [version 1; peer review: 2 approved]. F1000Research. 2019:8:1-13. https://doi.org/10.12688/f1000research.17119.1.

40. Fasth AER, Snir O, Johansson AAT, Nordmark B, Rahbar A, af Klint E, et al. Skewed distribution of proinflammatory CD4+CD28null T cells in rheumatoid arthritis. Arthritis Res Ther 2007;9. doi: https://doi.org/10.1186/ ar2286.

41. Chanouzas D, Sagmeister M, Faustini S, Nightingale P, Richter A, Ferro CJ, et al. Subclinical Reactivation of Cytomegalovirus Drives CD4 + CD28 null TCell Expansion and Impaired Immune Response to Pneumococcal Vaccination in Antineutrophil Cytoplasmic Antibody-Associated Vasculitis. J Infect Dis. 2019;219(Oxford University Press):234-44. https://doi.org/10.1093/ infdis/jiy493.

42. Maly K, Schirmer M. The story of CD4+CD28- T cells revisited: solved or still ongoing? J Immunol Res. 2015;2015. https://doi.org/10.1155/2015/348746.

43. Pierer M, Rothe K, Quandt D, Schulz A, Rossol M, Scholz R, et al. Association of anticytomegalovirus seropositivity with more severe joint destruction and more frequent joint surgery in rheumatoid arthritis. Arthritis Rheum. 2012; 64:1740-9. https://doi.org/10.1002/art.34346.

44. Broadley I, Pera A, Morrow G, Davies KA, Kern F. Expansions of cytotoxic CD4+CD28- T cells drive excess cardiovascular mortality in rheumatoid arthritis and other chronic inflammatory conditions and are triggered by CMV infection. Front Immunol. 2017:8:1-10. https://doi.org/10.3389/fimmu. 2017.00195

45. Almanzar G, Schmalzing M, Trippen R, Höfner K, Weißbrich B, Geissinger E, et al. Significant IFNy responses of CD8+ T cells in CMV-seropositive individuals with autoimmune arthritis. J Clin Virol. 2016;77:77-84. https://doi. org/10.1016/j.jcv.2016.02.010.

46. Larionova RV, Arleevskaya MI, Kravtsova OA, Validov S, Renaudineau Y. In seroconverted rheumatoid arthritis patients a multi-reactive anti-herpes IgM profile is associated with disease activity. Clin Immunol. 2019;200:19-23. https://doi.org/10.1016/j.clim.2019.01.004. 
47. Frimpong A, Kusi KA, Adu-Gyasi D, Amponsah J, Ofori MF, Ndifon W Phenotypic evidence of $\mathrm{T}$ cell exhaustion and senescence during symptomatic plasmodium falciparum malaria. Front Immunol. 2019;10. https://doi.org/10.3389/fimmu.2019.01345.

48. Caruso A, Fiorentini S, Licenziati S, Alessandri G, Ricotta D, Imberti L, et al. Expansion of rare CD8 +CD28 -CD11b - T cells with impaired effector functions in HIV-1-infected patients. J Acquir Immune Defic Syndr. 2000;24 465-74. https://doi.org/10.1097/00126334-200008150-00012.

49. Pillat MMM, Correa BLBL, da Rocha CFKCFK, Müller GCGC, Lopes RPRP, Lampert SSS, et al. Changes in T cell phenotype and activated MAPKs are correlated to impaired cellular responses to antigens and glucocorticoids during HTLV-I infection. J Neuroimmunol. 2009;216:76-84. https://doi.org/10. 1016/j.jneuroim.2009.08.016.

50. Solomon DH, Karlson EW, Rimm EB, Cannuscio CC, Mandl LA, Manson JAE, et al. Cardiovascular morbidity and mortality in women diagnosed with rheumatoid arthritis. Circulation. 2003;107:1303-7. https://doi.org/10.1161/01. CIR.0000054612.26458.B2.

51. Goronzy JJ, Matteson EL, Fulbright JW, Warrington KJ, Chang-Miller A, Hunder GG, et al. Prognostic markers of radiographic progression in early rheumatoid arthritis. Arthritis Rheum. 2004;50:43-54. https://doi.org/10.1002/ art.11445.

52. Bryl E, Vallejo AN, Matteson EL, Witkowski JM, Weyand CM, Goronzy JJ. Modulation of CD28 expression with anti-tumor necrosis factor a therapy in rheumatoid arthritis. Arthritis Rheum. 2005;52:2996-3003. https://doi.org/10. 1002/art.21353.

53. Weng N, Akbar AN, Goronzy J. CD28- T cells : their role in the ageassociated decline of immune function. Trends Immunol. 2009;30:306-12. https://doi.org/10.1016/j.it.2009.03.013.

54. Sawai H, Park YW, Roberson J, Imai T, Goronzy JJ, Weyand CM. T cell costimulation by fractalkine-expressing synoviocytes in rheumatoid arthritis. Arthritis Rheum. 2005;52:1392-401. https://doi.org/10.1002/art.21140.

55. Fessler J, Husic R, Schwetz V, Lerchbaum E, Aberer F, Fasching P, et al. Senescent T-cells promote bone loss in rheumatoid arthritis. Front Immunol. 2018:9:1-9. https://doi.org/10.3389/fimmu.2018.00095.

56. Guo Q, Wang Y, Xu D, Nossent J, Pavlos NJ, Xu J. Rheumatoid arthritis: pathological mechanisms and modern pharmacologic therapies. Bone Res. 2018;6:1-14. https://doi.org/10.1038/s41413-018-0016-9.

57. Steffen $U$, Schett $G$, Bozec A. How autoantibodies regulate osteoclast induced bone loss in rheumatoid arthritis. Front Immunol. 2019;10. https:// doi.org/10.3389/fimmu.2019.01483.

58. Sargin G, Kose R, Senturk T. Relationship between bone mineral density and anti-citrullinated protein antibody and rheumatoid factor in patients with rheumatoid arthritis. Eur J Rheumatol. 2019;6:29-32. https://doi.org/10.5152/ eurjrheum.2018.18099.

59. Kleyer A, Finzel S, Rech J, Manger B, Krieter M, Faustini F, et al. Bone loss before the clinical onset of rheumatoid arthritis in subjects with anticitrullinated protein antibodies. Ann Rheum Dis. 2014;73:854-60. https:// doi.org/10.1136/annrheumdis-2012-202958.

60. Maruotti N, Corrado A, Cantatore FP. Osteoporosis and rheumatic diseases. Reumatismo. 2014;66:125-35. https://doi.org/10.4081/reumatismo.2014.785

61. Heinlen L, Humphrey MB. Skeletal complications of rheumatoid arthritis. Osteoporos Int. 2017;28:2801-12. https://doi.org/10.1007/s00198-017-4170-5.

62. Crowson CS, Liao KP, Davis JM, Solomon DH, Matteson EL, Knutson KL, et al. Rheumatoid arthritis and cardiovascular disease. Am Heart J. 2013;166:6228. https://doi.org/10.1016/j.ahj.2013.07.010.

63. Fabbri E, An Y, Zoli M, Simonsick EM, Guralnik JM, Bandinelli S, et al. Aging and the burden of multimorbidity: associations with inflammatory and anabolic hormonal biomarkers. J Gerontol Ser A. 2015;70:63-70. https://doi. org/10.1093/gerona/glu127.

64. Ferrucci L, Fabbri E. Inflammageing: chronic inflammation in ageing, cardiovascular disease, and frailty. Nat Rev Cardiol. 2018;15:505-22. https:// doi.org/10.1038/s41569-018-0064-2.

65. Solomon DH, Reed GW, Kremer JM, Curtis JR, Farkouh ME, Harrold LR, et al. Disease activity in rheumatoid arthritis and the risk of cardiovascular events. Arthritis Rheumatol. 2015;67:1449-55. https://doi.org/10.1002/art.39098.

66. Swirski FK, Nahrendorf M. Cardioimmunology: the immune system in cardiac homeostasis and disease. Nat Rev Immunol. 2018;18:733-44. https:// doi.org/10.1038/s41577-018-0065-8.

67. Gerli R, Schillaci G, Giordano A, Bocci EB, Bistoni O, Vaudo G, et al. CD4+ CD28- $T$ lymphocytes contribute to early atherosclerotic damage in rheumatoid arthritis patients. Circulation. 2004;109:2744-8. https://doi.org/ 10.1161/01.CIR.0000131450.66017.B3.

68. Liuzzo G, Kopecky SL, Frye RL, O'Fallon WM, Maseri A, Goronzy JJ, et al. Perturbation of the T-cell repertoire in patients with unstable angina. Circulation. 1999;100:2135-9. https://doi.org/10.1161/01.CIR.100.21.2135.

69. Alber HF, Duftner C, Wanitschek M, Dörler J, Schirmer M, Suessenbacher A, et al. Neopterin, CD4+CD28- lymphocytes and the extent and severity of coronary artery disease. Int J Cardiol. 2009;135:27-35. https://doi.org/10. 1016/j.jijcard.2008.03.010.

70. Dumitriu IE, Araguás ET, Baboonian C, Kaski JC. CD4+CD28null T cells in coronary artery disease: when helpers become killers. Cardiovasc Res. 2009; 81:11-9. https://doi.org/10.1093/cvr/cvn248.

71. Koller L, Richter B, Goliasch G, Blum S, Korpak M, Zorn G, et al. CD4+ CD28null cells are an independent predictor of mortality in patients with heart failure. Atherosclerosis. 2013;230:414-6. https://doi.org/10.1016/j. atherosclerosis.2013.08.008

72. Xing GQ, Russell S, Webster MJ, Post RM. Decreased expression of mineralocorticoid receptor mRNA in the prefrontal cortex in schizophrenia and bipolar disorder. Int J Neuropsychopharmacol. 2004;7:143-53. https:// doi.org/10.1017/S1461145703004000.

73. Degré M. Has cytomegalovirus infection any role in the development of atherosclerosis? Clin Microbiol Infect. 2002;8:191-5. https://doi.org/10.1046/j. 1469-0691.2002.00407.x.

74. Cheng J, Ke Q, Jin Z, Wang H, Kocher O, Morgan JP, et al. Cytomegalovirus infection causes an increase of arterial blood pressure. PLoS Pathog. 2009;5. https://doi.org/10.1371/journal.ppat.1000427.

75. Pachnio A, Ciaurriz M, Begum J, Lal N, Zuo J, Beggs A, et al. Cytomegalovirus infection leads to development of high frequencies of cytotoxic virus-specific CD4+ T cells targeted to vascular endothelium. PLoS Pathog. 2016;12. https://doi.org/10.1371/journal.ppat.1005832.

76. Yurochko AD, Hwang ES, Rasmussen L, Keay S, Pereira L, Huang ES. The human cytomegalovirus UL55 (gB) and UL75 (gH) glycoprotein ligands initiate the rapid activation of Sp1 and NF-kappaB during infection. J Virol. 1997;71:5051-9. https://doi.org/10.1128/jvi.71.7.5051-5059.1997.

77. Samani NJ, Boultby R, Butler R, Thompson JR, Goodall AH. Telomere shortening in atherosclerosis. Lancet. 2001;358:472-3. https://doi.org/10. 1016/S0140-6736(01)05633-1.

78. Ormseth MJ, Solus JF, Oeser AM, Bian A, Gebretsadik T, Shintani A, et al. Telomere length and coronary atherosclerosis in rheumatoid arthritis. J Rheumatol. 2016;43:1469-74. https://doi.org/10.3899/jrheum.151115.

79. Prelog M. Aging of the immune system: A risk factor for autoimmunity? Autoimmun Rev. 2006;5:136-9. https://doi.org/10.1016/j.autrev.2005.09.008.

80. Petersen LE, Baptista TSA, Molina JK, Motta JG, do Prado A, Piovesan DM, et al. Cognitive impairment in rheumatoid arthritis: role of lymphocyte subsets, cytokines and neurotrophic factors. Clin Rheumatol. 2018;37:117181. https://doi.org/10.1007/s10067-018-3990-9.

81. Appenzeller S, Bértolo MB, Costallat LTL. Cognitive impairment in rheumatoid arthritis. Methods Find Exp Clin Pharmacol. 2004;26:339-43. https://doi.org/10.1358/mf.2004.26.5.831324.

82. Said FA, Betoni TB, Magalhaes V, Nisihara R, Skare TL. Rheumatoid arthritis and cognition dysfunction: lack of association with cumulative glucocorticoid use. Immunopharmacol Immunotoxicol. 2019;41:565-7. https://doi.org/10.1080/08923973.2019.1679170.

83. Trollor JN, Smith E, Agars E, Kuan SA, Baune BT, Campbell L, et al. The association between systemic inflammation and cognitive performance in the elderly: the Sydney memory and ageing study. Age (Omaha). 2012;34: 1295-308. https://doi.org/10.1007/s11357-011-9301-x.

84. Komulainen P, Lakka TA, Kivipelto M, Hassinen M, Penttilã IM, Helkala EL, et al. Serum high sensitivity C-reactive protein and cognitive function in elderly women. Age Ageing. 2007;36:443-8. https://doi.org/10.1093/ageing/ afm051.

85. van den Kommer TN, Dik MG, Comijs HC, Jonker C, Deeg DJH. Homocysteine and inflammation: predictors of cognitive decline in older persons? Neurobiol Aging. 2010;31:1700-9. https://doi.org/10.1016/j. neurobiolaging.2008.09.009.

86. Engelhardt B, Ransohoff RM. The ins and outs of T-lymphocyte trafficking to the CNS: anatomical sites and molecular mechanisms. Trends Immunol. 2005;26:485-95. https://doi.org/10.1016/j.it.2005.07.004.

87. Warren-Gash C, Forbes HJ, Williamson E, Breuer J, Hayward AC, Mavrodaris A, et al. Human herpesvirus infections and dementia or mild cognitive 
impairment: a systematic review and meta-analysis. Sci Rep. 2019;9. https:// doi.org/10.1038/s41598-019-41218-w.

88. Baptista TSA, Petersen LE, Molina JK, de Nardi T, Wieck A, do Prado A, et al Autoantibodies against myelin sheath and $\mathrm{S100} \beta$ are associated with cognitive dysfunction in patients with rheumatoid arthritis. Clin Rheumatol. 2017;36:1959-68. https://doi.org/10.1007/s10067-017-3724-4.

89. Hagberg $\mathrm{H}$, Mallard C. Effect of inflammation on central nervous system development and vulnerability. Curr Opin Neurol. 2005;18:117-23. https:// doi.org/10.1097/01.wco.0000162851.44897.8f.

90. Hamed SA, Selim ZI, Elattar AM, Elserogy YM, Ahmed EA, Mohamed HO. Assessment of biocorrelates for brain involvement in female patients with rheumatoid arthritis. Clin Rheumatol. 2012;31:123-32. https://doi.org/10. 1007/s10067-011-1795-1.

91. Joaquim AF, Appenzeller S. Neuropsychiatric manifestations in rheumatoid arthritis. Autoimmun Rev. 2015;14:1116-22. https://doi.org/10.1016/j.autrev. 2015.07.015.

92. Matcham F, Davies R, Hotopf M, Hyrich KL, Norton S, Steer S, et al. The relationship between depression and biologic treatment response in rheumatoid arthritis: An analysis of the British Society for Rheumatology Biologics Register. Rheumatol (United Kingdom). 2018;57:835-43. https://doi. org/10.1093/rheumatology/kex528.

93. Matcham F, Rayner L, Steer S, Hotopf M. The prevalence of depression in rheumatoid arthritis: A systematic review and meta-analysis. Rheumatol (United Kingdom) 2013;52:36-48. doi: https://doi.org/10.1093/rheumatology/ ket169.

94. Nerurkar L, Siebert S, Mclnnes IB, Cavanagh J. Rheumatoid arthritis and depression: an inflammatory perspective. Lancet Psychiatry. 2019;6:164-73. https://doi.org/10.1016/S2215-0366(18)30255-4.

95. Miller $\mathrm{AH}$, Maletic $\mathrm{V}$, Raison CL. Inflammation and its discontents: the role of cytokines in the pathophysiology of major depression. Biol Psychiatry 2009; 65:732-741. https://doi.org/S0006-3223(08)01532-1 [pii]https://doi.org/10. 1016/j.biopsych.2008.11.029.

96. qi FK, yuan $L Y$, li WH, tao $M X$, xin GJ, Wang F, et al. Stress-Induced Metabolic Disorder in Peripheral CD4+ T Cells Leads to Anxiety-like Behavior. Cell. 2019;179:864-879.e19. https://doi.org/10.1016/j.cell.2019.10. 001.

97. Kapoor SR, Filer A, Fitzpatrick MA, Fisher BA, Taylor PC, Buckley CD, et al. Metabolic profiling predicts response to anti-tumor necrosis factor a therapy in patients with rheumatoid arthritis. Arthritis Rheum. 2013;65:144856. https://doi.org/10.1002/art.37921.

98. Zhang F, Wei K, Slowikowski K, Fonseka CY, Rao DA, Kelly S, et al. Defining inflammatory cell states in rheumatoid arthritis joint synovial tissues by integrating single-cell transcriptomics and mass cytometry. Nat Immunol. 2019;20:928-42. https://doi.org/10.1038/s41590-019-0378-1.

99. Duggal NA, Upton J, Phillips AC, Hampson P, Lord JM. Depressive symptoms post hip fracture in older adults are associated with phenotypic and functional alterations in T cells. Immun Ageing. 2014;11:1-16. https:// doi.org/10.1186/s12979-014-0025-5.

100. Bauer ME, Teixeira AL. Inflammation in psychiatric disorders: what comes first? Ann N Y Acad Sci. 2018;1437:57-67. https://doi.org/10.1111/nyas.13712.

101. Dantzer R, O'Connor JC, Freund GG, Johnson RW, Kelley KW. From inflammation to sickness and depression: when the immune system subjugates the brain. Nat Rev Neurosci 2008;9:46-56. https://doi.org/nrn22 97 [pii]https://doi.org/10.1038/nrn2297.

102. Miller $\mathrm{AH}$, Raison $\mathrm{CL}$. The role of inflammation in depression: from evolutionary imperative to modern treatment target. Nat Rev Immunol. 2016;16:22-34. https://doi.org/10.1038/nri.2015.5.

103. Steiner J, Walter M, Gos T, Guillemin GJ, Bernstein HG, Sarnyai Z, et al. Severe depression is associated with increased microglial quinolinic acid in subregions of the anterior cingulate gyrus: evidence for an immunemodulated glutamatergic neurotransmission? J Neuroinflammation. 2011;8: 94. https://doi.org/10.1186/1742-2094-8-94.

104. Hardingham GE, Fukunaga Y, Bading H. Extrasynaptic NMDARs oppose synaptic NMDARs by triggering CREB shut-off and cell death pathways. Nat Neurosci. 2002;5:405-14. https://doi.org/10.1038/nn835.

105. Nance DM, Sanders VM. Autonomic innervation and regulation of the immune system (1987-2007). Brain Behav Immun. 2007;21:736-45. https:// doi.org/10.1016/j.bbi.2007.03.008

106. Di Benedetto S, Müller L, Wenger E, Düzel S, Pawelec G. Contribution of neuroinflammation and immunity to brain aging and the mitigating effects of physical and cognitive interventions. Neurosci Biobehav Rev. 2017;75: 114-28. https://doi.org/10.1016/j.neubiorev.2017.01.044.

107. Guan Z, Fang J. Peripheral immune activation by lipopolysaccharide decreases neurotrophins in the cortex and hippocampus in rats. Brain Behav Immun. 2006;20:64-71. https://doi.org/10.1016/j.bbi.2005.04.005

108. Grimsholm O, Rantapää-Dahlqvist S, Dalén T, Forsgren S. BDNF in RA: Downregulated in plasma following anti-TNF treatment but no correlation with inflammatory parameters. Clin Rheumatol. 2008;27:1289-97. https://doi. org/10.1007/s10067-008-0910-4.

109. Kerschensteiner M, Gallmeier E, Behrens L, Leal W, Misgeld T, Klinkert WEF, et al. Activated human T cells, B cells, and monocytes produce brainderived neurotrophic factor in vitro and in inflammatory brain lesions: A neuroprotective role of inflammation? J Exp Med. 1999;189:865-70. https:// doi.org/10.1084/jem.189.5.865.

110. Appel E, Kolman O, Kazimirsky G, Blumberg PM, Brodie C. Regulation of GDNF expression in cultured astrocytes by inflammatory stimuli. Neuroreport. 1997;8:3309-12. https://doi.org/10.1097/00001756-19971020000023.

111. Goehler LE, Gaykema RP, Nguyen KT, Lee JE, Tilders FJ, Maier SF, et al. Interleukin-1beta in immune cells of the abdominal vagus nerve: a link between the immune and nervous systems? J Neurosci. 1999;19:2799-806.

112. Blalock JE. The immune system as a sensory organ. J Immunol. 1984;132: 1067-70.

113. Pavlov VA, Tracey KJ. The vagus nerve and the inflammatory reflex--linking immunity and metabolism. Nat Rev Endocrinol. 2012;8:743-54. https://doi. org/10.1038/nrendo.2012.189.

114. Tracey KJ. The inflammatory reflex. Nature. 2002;420:853-9. https://doi.org/ 10.1038/nature01321.

115. Rosas-Ballina M, Olofsson PS, Ochani M, Valdes-Ferrer SI, Levine YA, Reardon $C$, et al. Acetylcholine-synthesizing $T$ cells relay neural signals in a vagus nerve circuit. Science (80- ). 2011;334:98-101. https://doi.org/10.1126/ science. 1209985.

116. Watkins LR, Maier SF. The pain of being sick: implications of immune-tobrain communication for understanding pain. Annu Rev Psychol. 2000;51: 29-57. https://doi.org/10.1146/annurev.psych.51.1.29.

117. Wang H, Yu M, Ochani M, Amella CA, Tanovic M, Susarla S, et al. Nicotinic acetylcholine receptor alpha7 subunit is an essential regulator of inflammation. Nature. 2003:421:384-8. https://doi.org/10.1038/nature01339.

118. von Känel R, Nelesen RA, Mills PJ, Ziegler MG, Dimsdale JE. Relationship between heart rate variability, interleukin-6, and soluble tissue factor in healthy subjects. Brain Behav Immun. 2008;22:461-8. https://doi.org/10. 1016/j.bbi.2007.09.009.

119. Thayer JF, Fischer JE. Heart rate variability, overnight urinary norepinephrine and C-reactive protein: evidence for the cholinergic anti-inflammatory pathway in healthy human adults. J Intern Med. 2009;265:439-47. https:// doi.org/10.1111/j.1365-2796.2008.02023.x.

120. Lindgren S, Stewenius J, Sjölund K, Lilja B, Sundkvist G. Autonomic vagal nerve dysfunction in patients with ulcerative colitis. Scand J Gastroenterol. 1993;28:638-42. https://doi.org/10.3109/00365529309096103.

121. Stein KS, McFarlane IC, Goldberg N, Ginzler EM. Heart rate variability in patients with systemic lupus erythematosus. Lupus. 1996;5:44-8.

122. Evrengül H, Dursunoglu D, Cobankara V, Polat B, Seleci D, Kabukçu S, et al. Heart rate variability in patients with rheumatoid arthritis. Rheumatol Int. 2004;24:198-202. https://doi.org/10.3329/jbsp.v7i2.14455.

123. Koopman FA, Chavan SS, Miljko S, Grazio S, Sokolovic S, Schuurman PR, et al. Vagus nerve stimulation inhibits cytokine production and attenuates disease severity in rheumatoid arthritis. Proc Natl Acad Sci U S A. 2016;113: 8284-9. https://doi.org/10.1073/pnas.1605635113.

124. Schwartz M, Kipnis J, Rivest S, Prat A. How do immune cells support and shape the brain in health, disease, and aging? J Neurosci. 2013;33:17587-96. https://doi.org/10.1523/JNEUROSCI.3241-13.2013.

125. Sawada A, Niiyama Y, Ataka K, Nagaishi K, Yamakage M, Fujimiya M. Suppression of bone marrow-derived microglia in the amygdala improves anxiety-like behavior induced by chronic partial sciatic nerve ligation in mice. Pain. 2014;155:1762-72. https://doi.org/10.1016/j.pain.2014.05.031.

126. Degos V, Vacas S, Han Z, van Rooijen N, Gressens P, Su H, et al. Depletion of bone marrow-derived macrophages perturbs the innate immune response to surgery and reduces postoperative memory dysfunction. Anesthesiology. 2013;118:527-36. https://doi.org/10.1097/ALN.0b013e3182834d94.

127. Wohleb ES, McKim DB, Sheridan JF, Godbout JP. Monocyte trafficking to the brain with stress and inflammation: a novel axis of immune-to-brain 
communication that influences mood and behavior. Front Neurosci. 2014;8: 447. https://doi.org/10.3389/fnins.2014.00447.

128. Giunta B, Fernandez F, Nikolic WV, Obregon D, Rrapo E, Town T, et al. Inflammaging as a prodrome to Alzheimer's disease. J Neuroinflammation. 2008;5:1-15. https://doi.org/10.1186/1742-2094-5-51.

129. Cohen H, Ziv Y, Cardon M, Kaplan Z, Matar MA, Gidron Y, et al. Maladaptation to mental stress mitigated by the adaptive immune system via depletion of naturally occurring regulatory $C D 4+C D 25+$ cells. J Neurobiol. 2006;66:552-63. https://doi.org/10.1002/neu.20249.

130. Kipnis J, Cohen H, Cardon M, Ziv Y, Schwartz M. T cell deficiency leads to cognitive dysfunction: implications for therapeutic vaccination for schizophrenia and other psychiatric conditions. Proc Natl Acad Sci U S A. 2004;101:8180-5. https://doi.org/10.1073/pnas.0402268101.

131. Ziv Y, Ron N, Butovsky O, Landa G, Sudai E, Greenberg N, et al. Immune cells contribute to the maintenance of neurogenesis and spatial learning abilities in adulthood. Nat Neurosci. 2006;9:268-75. https://doi.org/10.1038/ nn1629.

132. Kipnis J, Gadani S, Derecki NC. Pro-cognitive properties of T cells. Nat Rev Immunol. 2012;12:663-9. https://doi.org/10.1038/nri3280.

133. Derecki NC, Cardani AN, Yang CH, Quinnies KM, Crihfield A, Lynch KR, et al. Regulation of learning and memory by meningeal immunity: a key role for IL-4. J Exp Med. 2010;207:1067-80. https://doi.org/10.1084/jem.20091419.

134. Baruch K, Deczkowska A, David E, Castellano JM, Miller O, Kertser A, et al. Aging. Aging-induced type I interferon response at the choroid plexus negatively affects brain function. Science (80- ). 2014;346:89-93. https://doi. org/10.1126/science.1252945.

135. Ribeiro M, Brigas HC, Temido-Ferreira M, Pousinha PA, Regen T, Santa C, et al. Meningeal $\gamma \delta$ T cell-derived IL-17 controls synaptic plasticity and short-term memory. Sci Immunol. 2019;4:1-13.

136. Li Y, Shen Y, Jin K, Wen Z, Cao W, Wu B, et al. The DNA Repair Nuclease MRE11A Functions as a Mitochondrial Protector and Prevents T Cell Pyroptosis and Tissue Inflammation. Cell Metab. 2019;30:477-492.e6. https:// doi.org/10.1016/j.cmet.2019.06.016.

137. Raveney BJE, Oki S, Hohjoh H, Nakamura M, Sato W, Murata M, et al. Eomesodermin-expressing T-helper cells are essential for chronic neuroinflammation. Nat Commun. 2015;6:1-11. https://doi.org/10.1038/ ncomms9437.

138. Chemin K, Ramsköld D, Diaz-Gallo LM, Herrath J, Houtman M, Tandre K, et al. EOMES-positive CD4+ T cells are increased in PTPN22 (1858T) risk allele carriers. Eur J Immunol. 2018;48:655-69. https://doi.org/10.1002/eji. 201747296.

139. do Prado CH, Rizzo LB, Wieck A, Lopes RP, Teixeira AL, Grassi-Oliveira R, et al. Reduced regulatory $T$ cells are associated with higher levels of Th1/ TH17 cytokines and activated MAPK in type 1 bipolar disorder. Psychoneuroendocrinology. 2013;38:667-76. https://doi.org/10.1016/j. psyneuen.2012.08.005.

140. Do Prado CH, Grassi-Oliveira R, Daruy-Filho L, Wieck A, Bauer ME. Evidence for immune activation and resistance to glucocorticoids following childhood maltreatment in adolescents without psychopathology. Neuropsychopharmacology. 2017;42:2272-82. https://doi.org/10.1038/npp. 2017.137.

141. Larbi A, Pawelec G, Witkowski JM, Schipper HM, Derhovanessian E, Goldeck $D$, et al. Dramatic shifts in circulating CD4 but not CD8 T cell subsets in mild alzheimer's disease. J Alzheimers Dis. 2009;17:91-103. https:/doi.org/ 10.3233/JAD-2009-1015.

142. Pellicanò M, Larbi A, Goldeck D, Colonna-Romano G, Buffa S, Bulati M, et al. Immune profiling of Alzheimer patients. J Neuroimmunol. 2012;242:52-9. https://doi.org/10.1016/j.jneuroim.2011.11.005.

\section{Publisher's Note}

Springer Nature remains neutral with regard to jurisdictional claims in published maps and institutional affiliations.

Ready to submit your research? Choose BMC and benefit from:

- fast, convenient online submission

- thorough peer review by experienced researchers in your field

- rapid publication on acceptance

- support for research data, including large and complex data types

- gold Open Access which fosters wider collaboration and increased citations

- maximum visibility for your research: over $100 \mathrm{M}$ website views per year

At $\mathrm{BMC}$, research is always in progress.

Learn more biomedcentral.com/submissions 